TITLE:

\title{
Poecilostomatoid Copepods Parasitic in the Scleractinian Coral Genus Goniastrea in the Moluccas
}

\section{$\operatorname{AUTHOR}(\mathrm{S})$ :}

Humes, Arthur G.

\section{CITATION:}

Humes, Arthur G.. Poecilosto mato id Copepods Parasitic in the Scleractinian Coral Genus Goniastrea in the Moluccas. PUBLICATIONS OF THE SETO MARINE BIOLOGICAL LABORATORY 1985, 30(4-6): 277-286

ISSUE DATE:

1985-12-25

URL:

http://hdl.handle.net/2433/176109

RIGHT: 


\title{
Poecilostomatoid Copepods Parasitic in the Scleractinian Coral Genus Goniastrea in the Moluccas
}

\author{
By \\ Arthur G. Humes \\ Boston University Marine Program, Marine Biological Laboratory, \\ Woods Hole, Massachusetts, U.S.A. 02543 \\ With Text-figures $1-4$
}

\begin{abstract}
Two new copepods (Poecilostomatoida) are reported from the scleractinian coral Goniastrea retiformis (Lamarck) at Poelau Parang, Ceram. Amarda goniastreae n. sp. (family Lichomolgidae) is distinguished from the two other known congeners by the 2-segmented endopods of legs 1 and 2 and by the second segment of the exopod of leg 3 having only 2 spines. Parangium abstrusum n. gen., n. sp. (family uncertain), known only from one female, has an elongate body, with legs 1 and 2 biramous but legs 3 and 4 uniramous, the endopod being absent. Leg 5 is absent.
\end{abstract}

Although more than 170 species of copepods are known to be associated with Scleractinia, only one species, the harpacticoid Alteuthellopsis corallina Humes, 1981, has been reported from Goniastrea retiformis (Lamarck). This peltidiid copepod was collected at Poelau Parang, Ceram (Humes, 1981), the type locality of the two new forms described here.

The two new copepods from Goniastrea retiformis that are the subject of this paper were collected by the author during the Alpha Helix East Asian Bioluminescence Expedition, which was supported by the National Science Foundation of the United States, under grants OFS 7401830 and OFS 7402888 to the Scripps Institution of Oceanography and grant BMS 7423242 to the University of California, Santa Barbara.

The procedure for the collection of the copepods was that outlined by Humes (1978).

I thank Dr. John W. Wells, Department of Geological Sciences, Cornell University, for the identification of the host coral.

All figures were drawn with the aid of a camera lucida. The letter after the explanation of each figure refers to the scale at which it was drawn. The abbreviations used are: $A_{1}=$ first antenna, $\mathrm{A}_{2}=$ second antenna, and $\mathrm{L}=$ labrum.

Lichomolgidae Kossmann, 1877

Amarda Humes et Stock, 1972

Amarda goniastreae n. sp.

(Figs $1 \mathrm{a}-\mathrm{h}, 2 \mathrm{a}-\mathrm{l}$ )

Publ. Seto Mar. Biol. Lab., 30(4/6), 277-286, 1985.

(Article 13) 
Type material: 4 우, $50^{\star} \hat{o}^{\lambda}$ from 1 colony of the faviid coral Goniastrea retiformis (Lamarck), in $2 \mathrm{~m}$, Poelau Parang, northeastern Ceram, Moluccas, $3^{\circ} 17^{\prime} 00^{\prime \prime} \mathrm{S}, 130^{\circ} 44^{\prime} 48^{\prime \prime} \mathrm{E}, 23$ May 1975. Holotype $Q$, allotype, and 4 paratypes $\left(1+9,30^{*} \delta^{*}\right)$ deposited in the National Museum of Natural History, Smithsonian Institution, Washington, D.C.: the remaining paratypes in the author's collection.

Female. Body (Fig. la, b) with broad thickened prosome. Length (not including setae on caudal rami) $0.75 \mathrm{~mm}(0.72-0.78 \mathrm{~mm})$ and greatest width $0.32 \mathrm{~mm}$ $(0.32-0.35 \mathrm{~mm})$, based on 4 specimens in lactic acid. Greatest dorsoventral thickness approximately $0.28 \mathrm{~mm}$. Ratio of length to width of prosome 1.78:1. Ratio of length of prosome to that of urosome 1.91:1. Segment of leg 1 set off from cephalosome by transverse dorsal furrow. Epimeral areas of segments of legs 2 and 3 prominent.

Segment of leg 5 (Fig. 1c) $180 \times 60 \mu \mathrm{m}$. Genital segment $112 \times 151 \mu \mathrm{m}$, broader than long, in dorsal view widest in anterior half; in lateral view (Fig. 1b) with dorsal hump. Genital areas located dorsolaterally. Each area (Fig. 1d) bearing 2 small spines about $5.5 \mu \mathrm{m}$ long, directed medially. Three postgenital segments from anterior to posterior $49 \times 88,42 \times 70$, and $52 \times 60 \mu \mathrm{m}$.

Caudal ramus (Fig. 1e) elongate, $44 \times 14 \mu \mathrm{m}$, ratio 3.14:1. Outer lateral seta $10 \mu \mathrm{m}$, dorsal seta $9 \mu \mathrm{m}$, and 4 terminal setae from outer to inner $11,34,39$, and $11 \mu \mathrm{m}$, median 2 of these setae much longer and stouter than others.

Body surface (Fig. la, b) with many refractile points on prosome: urosome without such ornamentation except for scattered small points on segment of leg 5 and genital segment.

Egg sac (Fig. If) $230 \times 180 \mu \mathrm{m}$ (in only sac seen), containing 3 eggs 100-125 $\mu \mathrm{m}$ in diameter.

Rostrum (Fig. 1g) broadly linguiform. First antenna (Fig. 1h) $173 \mu \mathrm{m}$ long and probably 7-segmented, although separation between last 2 segments not complete. Lengths of segments (measured along their posterior nonsetiferous margins): 18 (44 $\mu \mathrm{m}$ along anterior margin), $42,13,18,23,18$, and $10 \mu \mathrm{m}$, respectively. Formula for armature: $4,12,6,3,4+1$ aesthete, $2+1$ aesthete, and $7+1$ aesthete. All setae naked.

Second antenna (Fig. 2a) $180 \mu \mathrm{m}$ long and 3-segmented. First and second segments with inner seta. Third segment bearing 3 small inner setae, distal digitiform extension, and slightly sinuous terminal claw $31 \mu \mathrm{m}$.

Labrum (Fig. 2b) with deep median incision and 2 laterally directed posteroventral lobes. Mandible (Fig. 2c), first maxilla, second maxilla (Fig. 2d), and maxilliped (Fig. 2e) resembling those of Amarda cultrata Humes et Stock, 1973. Paragnath not seen. Second segment of maxilliped apparently with only 1 inner seta.

Ventral area between maxillipeds and first pair of legs as in $A$. cultrata.

Leg 1 (Fig. 2f) and leg 2 (Fig. 2g) with 3-segmented exopods and 2-segmented endopods. Leg 3 (Fig. 2h) with 2-segmented exopod but lacking endopod. Leg 4 absent. Armature of legs as follows (Roman numerals indicating spines, Arabic 


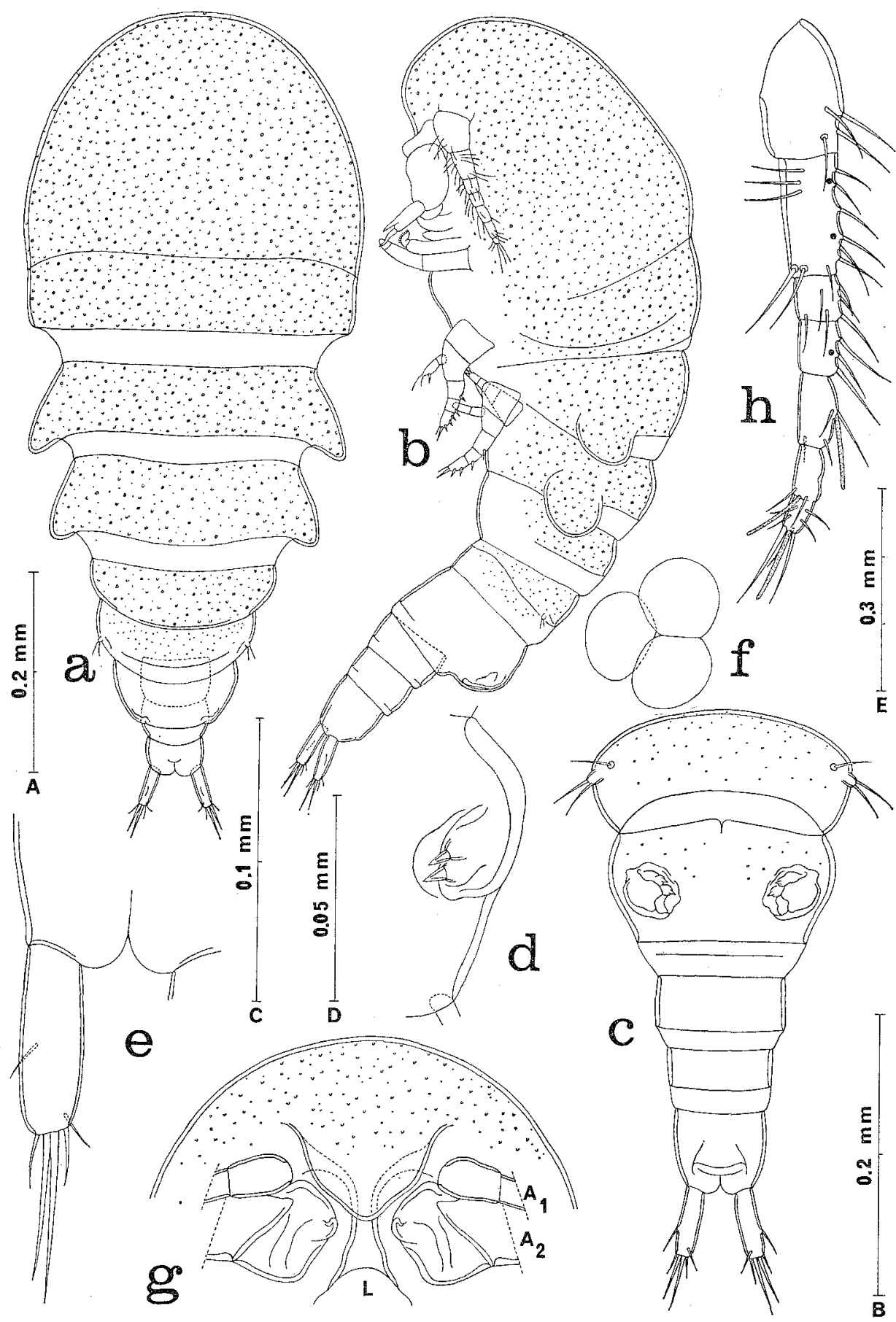

Fig. 1. Amarda goniastreae n. sp., female. a, dorsal (scale A); b, lateral (A); c, urosome, dorsal (B); d, genital area, dorsal (C); e, caudal ramus, ventral (D); f, egg sac, lateral (E); g, rostrum and adjacent area, ventral $(\mathbf{B}) ; \mathrm{h}$, first antenna, with dots indicating positions of three aesthetes added in male, anterior $\mathrm{C}$ ). 


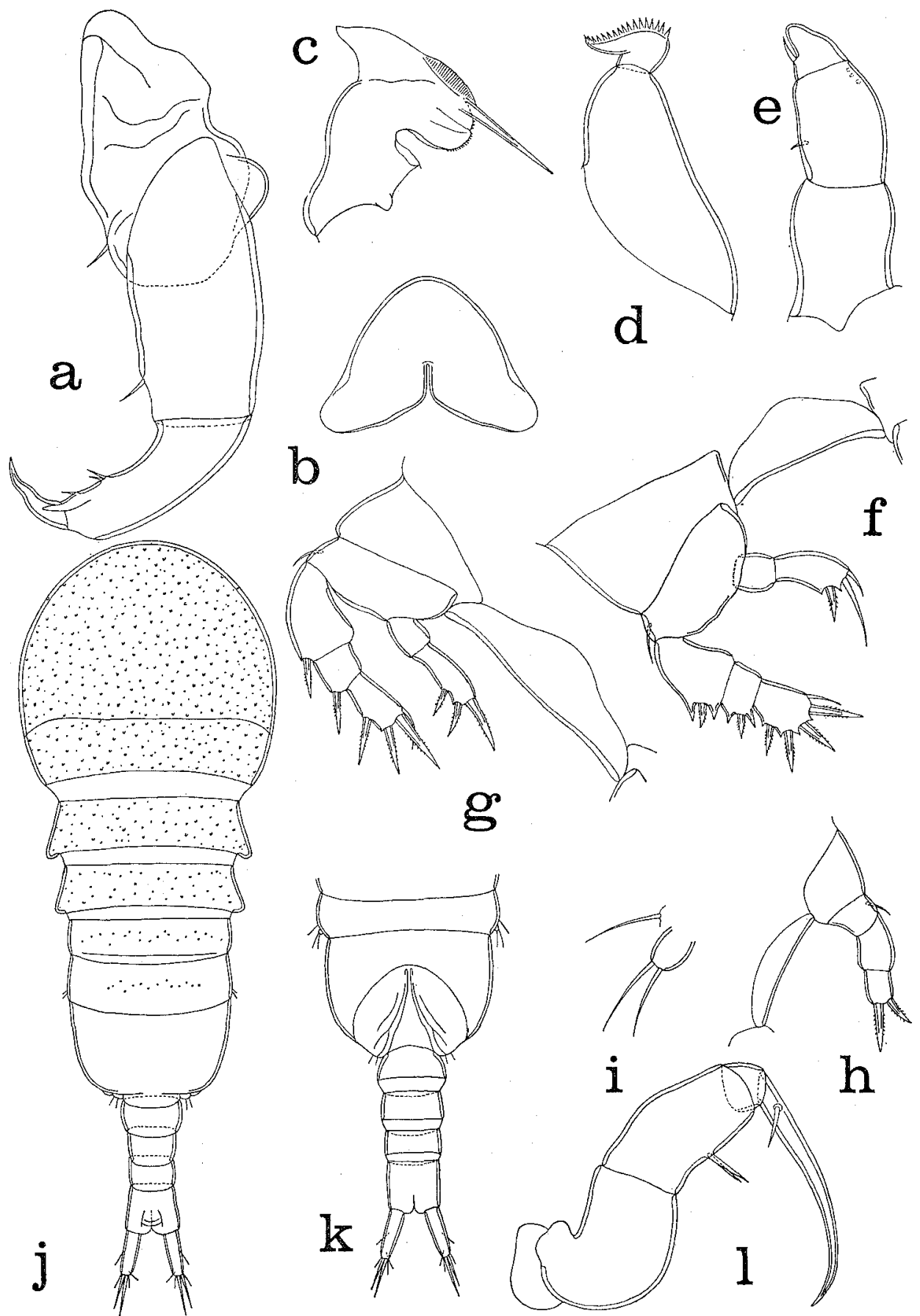

Fig. 2. Amarda goniastreae n. sp. Female: a, second antenna, anterior (scale C); b, labrum, ventral (C); c, mandikle, anterior (D); d, second maxilla, posterior (D); e, maxilliped, posterior (D); $f$, leg 1 and intercoxal plate, anterior (C);g, leg 2 and intercoxal plate, anterior $(C)$; $h$, leg 3 and intercoxal plate, anterior (C); 1 , leg 5 , lateral (D). Male: $j$, dorsal (A); $k$, urosome, ventral (A); 1, maxilliped, posterior (C). 
numerals representing setae):

$\begin{array}{ccccccccc}\mathrm{P}_{1} & \text { coxa } & 0-0 & \text { basis } & 1-0 & \exp & \mathrm{I}-0 ; & \mathrm{I}-0 ; & \text { III, I, } 1 \\ & & & & & \operatorname{enp} & 0-0 ; \mathrm{I}, 2 & \\ \mathrm{P}_{2} & \text { coxa } & 0-0 & \text { basis } & 1-0 & \exp & \mathrm{I}-0 ; \mathrm{I}-0 ; & \text { I, II, } 1 \\ & & & & & \operatorname{enp} & 0-0 ; \mathrm{I}, \mathrm{II} & \\ \mathrm{P}_{3} & \text { coxa } & 0-0 & \text { basis } & 1-0 & \exp & 0-0 ; \mathrm{II} & \\ & & & & & \operatorname{enp} & \text { absent } & \\ \mathrm{P}_{4} & \text { absent } & & & & & & \end{array}$

Leg 5 (Fig. 2i) with very small segment $8 \times 8 \mu \mathrm{m}$, not clearly separated from body, bearing 2 terminal setae approximately $34 \mu \mathrm{m}$; adjacent dorsal seta $34 \mu \mathrm{m}$.

Leg 6 probably represented by 2 small spines on genital area (Fig. 1d).

Color of living specimens in transmitted light opaque gray, eye dull reddish gray.

Male. Body (Fig. 2j) resembling in general form that of female. Length (excluding setae on caudal rami) $0.74 \mathrm{~mm}(0.72-0.78 \mathrm{~mm})$ and greatest width $0.25 \mathrm{~mm}(0.24-0.25 \mathrm{~mm})$, based on 4 specimens in lactic acid. Greatest dorsoventral thickness $0.21 \mathrm{~mm}$. Ratio of length to width of prosome 2.19:1. Ratio of length of prosome to that of urosome $3.16: 1$.

Segment of leg 5 (Fig. 2k) $34 \times 180 \mu \mathrm{m}$. Genital segment $120 \times 170 \mu \mathrm{m}$. Four postgenital segments from anterior to posterior $36 \times 68,36 \times 58,31 \times 52$, and 52 $\times 49 \mu \mathrm{m}$.

Caudal ramus like that of female.

Rostrum as in female. First antenna similar to that of female but 3 aesthetes added, so that formula is $3,12+2$ aesthetes, $6,3+1$ aesthete, $4+1$ aesthete, $2+1$ aesthete, and $7+1$ aesthete. Second antenna, labrum, mandible, first maxilla, and second maxilla as in female.

Maxilliped (Fig. 21) 4-segmented (assuming proximal part of claw to represent fourth segment). First segment unarmed. Second segment with 2 inner setae set very close together. Small third segment unarmed. Claw $84 \mu \mathrm{m}$, gently recurved, with proximal seta.

Ventral area between maxillipeds and first pair of legs as in female.

Legs 1-3 like those of female. Leg 4 absent.

Leg 5 resembling that of female but segment smaller.

Leg 6 represented by posteroventral flap on genital segment bearing 2 small setae (Fig. 2k).

Spermatophore not seen.

Color as in female.

Etymology. The specific name goniastreae refers to the genus name of the host coral.

Remarks. Two species of Amarda were described by Humes \& Stock (1973): Amarda cultrata and Amarda compta, both from Favia sp. in the vicinity of Nosy Bé, northwestern Madagascar. Amarda goniastreae, the third member of the genus, may 
be distinguished from its two congeners by the use of the following key.

Key to the species of Amarda

1. Endopods of legs 1 and 2 two-segmented 2 Endopods of legs 1 and 2 three-segmented A. compta

2. Second segment of exopod of leg 3 with formula I, II; two median terminal setae on caudal ramus broad and bladelike A. cultrata Second segment of exopod of leg 3 with formula II; two median terminal setae on caudal ramus slender

A. goniastreae

\section{Family uncertain}

\section{Parangium n. gen.}

Diagnosis (based on female). Body elongate, slender, weakly sclerotized, with prosome not much wider than urosome. Prosomal segments not separated by well-marked sutures. Caudal rami held laterally, nearly at right angles to body. First antenna short, 3-segmented. Second antenna 3-segmented, third segment incompletely subdivided, with single short terminal claw. Labrum broad without posteroventral lobes. Mandible with short stout blade. First maxilla with 2 setae. Second maxilla 2-segmented. Maxilliped 3-segmented. Legs 1 and 2 with 3segmented exopods and 2-segmented endopods. Legs 3 and 4 with 1-segmented exopods, endopods absent. Spines and setae short and smooth. Leg 5 absent.

Male unknown.

Type-species. Parangium abstrusum n. sp.

Gender neuter.

Etymology. The generic name is formed from Parang, the name of the island off northeastern Geram where the copepod was collected.

\section{Parangium abstrusum n. sp.}

$$
\text { (Figs 3a-g, 4a-j) }
$$

Type material: 1 ㅇ from Goniastrea retiformis (Lamarck), in $2 \mathrm{~m}$, Poelau Parang, northeastern Ceram, Moluccas, $3^{\circ} 17^{\prime} 00^{\prime \prime} \mathrm{S}, 130^{\circ} 44^{\prime} 48^{\prime \prime} \mathrm{E}, 23$ May 1975. Holotype deposited in the National Museum of Natural History, Smithsonian Institution, Washington, D.C.

Female. Body (Fig. 3a, b) elongate and slender, slightly arched dorsally. Length (not including setae on caudal rami) $2.64 \mathrm{~mm}$, width at segment of leg 2 $0.41 \mathrm{~mm}$, and width at first postgenital segment $0.39 \mathrm{~mm}$, based on specimen in lactic acid. Greatest dorsoventral thickness $0.42 \mathrm{~mm}$. Ratio of length to width of prosome approximately $4.1: 1$. Ratio of length of prosome to that of urosome $1.97: 1$. Segment of leg 1 set off from cephalosome by transverse dorsal furrow. Boundaries of pedigerous segments without distinct furrows; these segments indicated 

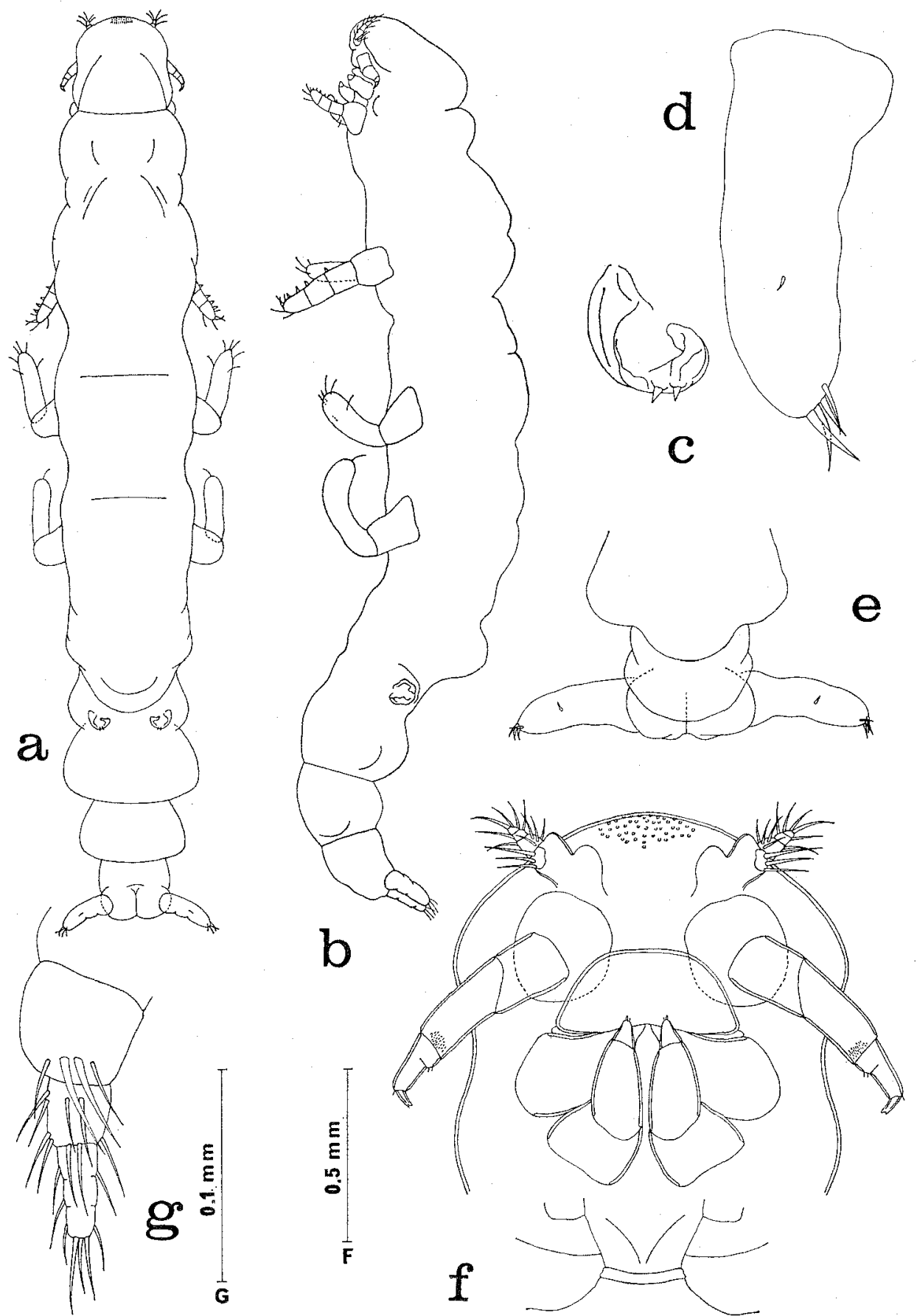

Fig. 3. Parangium abstrusum n. gen., n. sp., female. a, dorsal (scale F); b, lateral (F); c, genital area, dorsal $(G)$; d, caudal ramus, ventral $(G)$; e, posterior end of body, ventral (E); $f$, cephalosome, ventral $(B) ; g$, first antenna, ventral (D). 
by lateral swellings. Separation of postgenital segments more distinctly seen.

Urosome showing dorsal hump at level of absent leg 5 (Fig. 3b). Genital segment having 2 dorsolateral genital areas, each area (Fig. 3c) bearing 2 minute setae about $6 \mu \mathrm{m}$. Three postgenital segments.

Caudal ramus (Fig. 3d) elongate, $205 \mu \mathrm{m}$ long and $57 \mu \mathrm{m}$ wide at middle. Rami held at nearly right angles to body (Fig. 3e), with greatest lateral spread from tip of one ramus to tip of other $495 \mu \mathrm{m}$. Each ramus armed with 5 small setae, one on ventral surface and 4 terminal.

Body surface smooth except for patch of small refractile knobs on midanterior surface of head (Fig. 3f).

Egg sac not seen.

Rostrum not developed (Fig. 3f). First antenna (Fig. 3g) small, $65 \mu \mathrm{m}$ long, 3 -segmented (but third segment showing indication of subdivision into 3 segments). Numerous smooth setae. Second antenna (Fig. 4a) $146 \mu \mathrm{m}$ long, 3-segmented (but third segment partially divided). First segment with 1 inner seta. Second segment with 1 inner seta and distal inner patch of minute spines. Third segment with 2 minute proximal inner setae, 1 subterminal outer seta, and terminal claw $16 \mu \mathrm{m}$ with unequally bifid tip.

Labrum (Fig. 3f) broad, without posteroventral lobes. Mandible (Fig. 4b) sickle-shaped, with short stout blade having small marginal spines. Paragnath not seen. First maxilla (Fig. 4c) a small lobe with 2 terminal setae. Second maxilla (Fig. 4d) 2-segmented. First segment unarmed. Second segment with 1 ventral seta and having digitiform spinulose tip carrying 1 small seta. Maxilliped (Fig. 4e) 3-segmented. First segment unarmed. Second segment with 2 inner setae. Third segment with minute terminal seta and rows of very small spinules.

Ventral area between maxillipeds and first pair of legs without sclerotizations.

Leg 1 (Fig. 4f) and leg 2 (Fig. 4g) biramous, with 3-segmented exopods and 2-segmented endopods. Leg 3 (Fig. 4h) and leg 4 (Fig. 4i) uniramous, with 1segmented exopod, endopod absent. Formula for armature as follows:

$\begin{array}{lllllllll}\mathrm{P}_{1} & \text { coxa } & 0-0 & \text { basis } & 1-0 & \exp & \mathrm{I}-0 ; \mathrm{I}-0 ; & \mathrm{III}, 4 \\ & & & & \operatorname{enp} & 1-0 ; 6 & \\ \mathrm{P}_{2} & \text { coxa } 0-0 & \text { basis } & 1-0 & \exp & \mathrm{I}-0 ; \mathrm{I}-0 ; \mathrm{II}, 5 \\ & & & & \operatorname{enp} & 1-0 ; 3 & \\ \mathrm{P}_{3} & \text { coxa-basis } & 0-0 & & \exp & 6 \\ & & & & \operatorname{enp} & \text { absent } & \\ \mathrm{P}_{4} & \text { coxa-basis } & 0-0 & & \exp & 1 \text { or } 2 \\ & & & & & \text { enp absent }\end{array}$

Intercoxal plate only in leg 1 (Fig. 4f). All legs weakly sclerotized. Right leg 4 with 1 terminal seta (Fig. 4i), but left leg 4 with 2 such setae (Fig. $4 \mathrm{j}$ ).

Leg 5 absent.

Leg 6 probably represented by 2 minute setae on genital area (Fig. 3c).

Color of living specimen in transmitted light opaque gray, eye dull red.

Male. Unknown. 

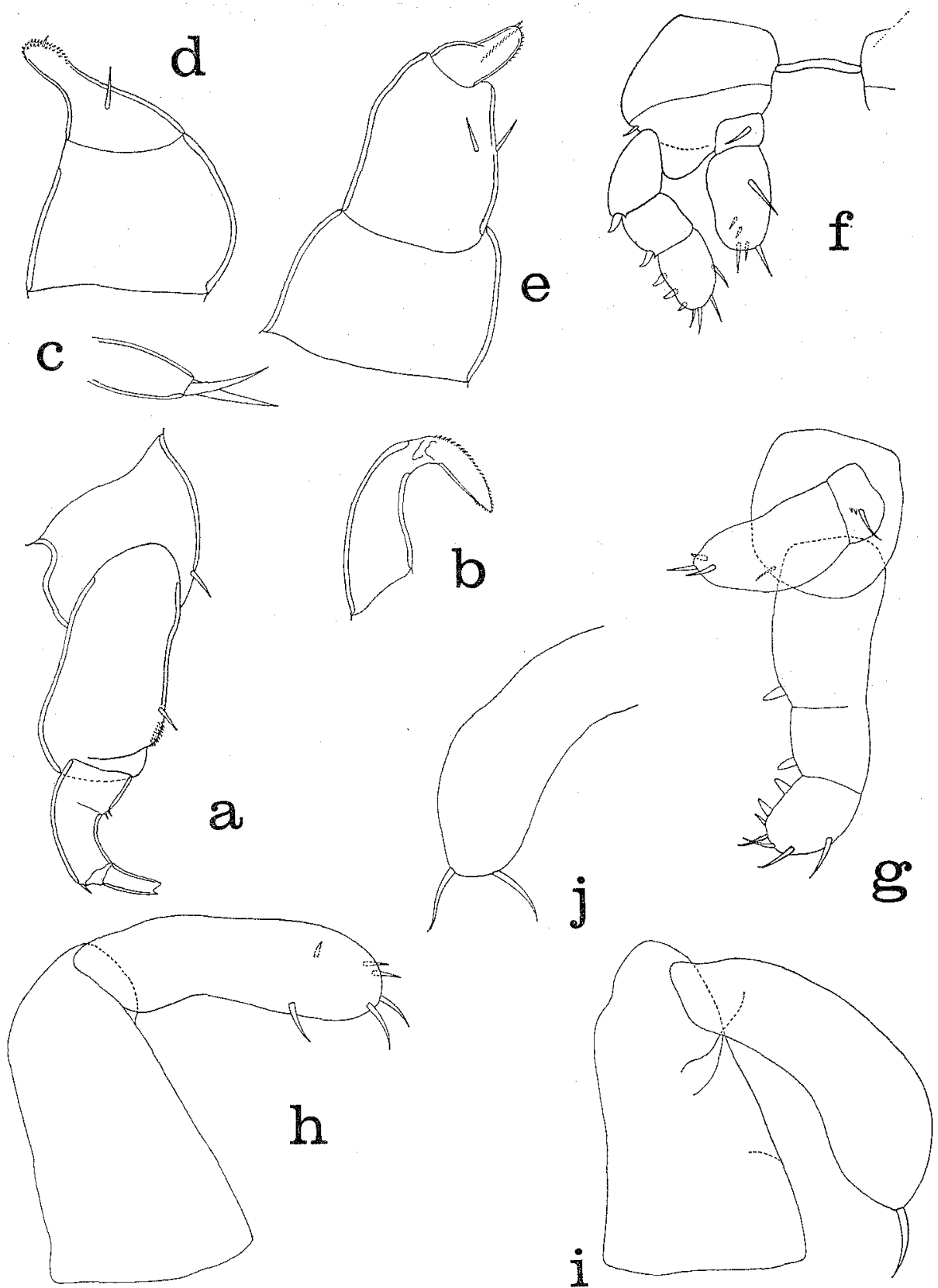

Fig. 4. Parangium abstrusum n. gen., n. sp., female. a, second antenna, anterior (scale C); b, mandible, outer (C); c, first maxilla, outer (C); d, second maxilla, ventral (C); e, maxilliped, inner (C); $f$, leg 1 and intercoxal plate, posteroventral (B); g, leg 2, posteroventral (B); h, leg 3, posteroventral (B); $i, \operatorname{leg} 4$, posteroventral (B); j, tip of left leg 4 , posteroventral (B). 
Etymology. The specific name abstrusum, Latin meaning concealed or hidden, alludes to the habitat within the coral polyps.

Remarks. While at first glance the general body form of Parangium suggests similarities with copepods belonging to the family Corallovexiidae Stock, 1975, from. West Indian corals, there are fundamental differences. The two genera of the Corallovexiidae are more transformed, lack clearly identifiable mandibles, have unsegmented thoracic lateral swellings, and small first and second thoracic pereiopods.

The mouthparts of Parangium resemble basically those of the Lichomolgoidea. Without knowledge of the male of Parangium it is difficult to assign this copepod from Goniastrea to a family, and, although Parangium is beyond doubt a poecilostomatoid copepod, its familial affiliation remains uncertain.

\section{References}

Humes, A.G. 1978. Lichomolgid copepods (Gyclopoida) associated with the coral genus Montipora in the Moluccas. Publ. Seto Mar. Biol. Lab., 24: 387-407.

1981. Harpacticoid copepods associated with Cnidaria in the Indo-West Pacific. J. Crust. Biol., $1: 227-240$.

—.., \& J.H. Stock. 1972. Preliminary notes on a revision of the Lichomolgidae, cyclopoid copepods mainly associated with marine invertebrates. Bull. Zool. Mus., Univ. Amsterdam, 2 (12): 121-133.

— \& 1973. A revision of the family Lichomolgidae Kossmann, 1877, cyclopoid copepods mainly associated with marine invertebrates. Smithsonian Contrib. Zool., no. 127, pp. 1-368.

Stock, J.H. 1975. Corallovexiidae, a new family of transformed copepods endoparasitic in reef corals. Stud. Fauna Guraçao and other Carib. Is., $47: 1-45$. 